\title{
The Interpretive Challenges of American Presidential Discourse Described as Joking (Russian Translation)
}

\section{Catherine Evans Davies (a); Maria V. Semikolennykh (translator)}

(a) The University of Alabama. Tuscaloosa, Alabama, USA. Email: cedavies08[at]gmail.com

(b) Russian Christian Humanitarian Academy. Saint Petersburg, Russia. Email: maria.semikolennykh[at]gmail.com

\section{Abstract}

When the American President speaks in a way that is later characterized as joking/kidding, a wide range of interpretations become possible. At a minimum, there are two basic interpretations: serious and non-serious. At the other extreme, there may be as many nuanced interpretations as there are audiences for the discourse. In this study, I will first examine the "just/only joking" strategy, considering how it fits within a theoretical understanding of humorous discourse, and lay out the prototypical strategic moves. Then I will explore how the two main audiences (the currently polarized political groupings in the United States) tend to interpret the "joking" in relation to the performance style of President Donald J. Trump. Using three examples, I will attempt to show how the same utterance can be interpreted by one audience as a harmless joke and by the other as a grave threat.

\section{Keywords}

Joking; Discourse; Politics; Usa; Trump; Kidding; Sarcasm; Interpretation; Polarization; Priming 


\section{Проблема интерпретации «шуточного» дискурса американского президента (перевод на русский язык)}

Дэвис Кэтрин Эванс (a), Семиколенных Мария Владимировна (переводчик) (b)

(a) Университет Алабамы. Таскалуса, Алабама, США. Email: cedavies08[at]gmail.com

(b) Русская христианская гуманитарная академия. Санкт-Петербург, Россия.

Email: maria.semikolennykh[at]gmail.com

\section{Аннотация}

Когда американский президент произносит нечто, впоследствии называемое шуткой или подтруниванием, возможны самые разные интерпретации. Как минимум, таких интерпретаций две: серьезная и несерьезная. Как максимум, подобных неоднозначных интерпретаций может быть столько же, сколько у президента типов слушателей. В данном исследовании я сначала рассмотрю стратегию «всего лишь / просто шутки» с точки зрения того, как она согласуется с теоретической трактовкой юмористического дискурса, и опишу классические ходы подобной стратегии. Затем я проанализирую то, как склонны интерпретировать «шутки» в речах президента Дональда Дж. Трампа две основные группы слушателей (в данный момент политически противостоящие друг другу аудитории в США), в связи со стилем его выступлений. С помощью трёх примеров я продемонстрирую, как одно и то же высказывание одной аудиторией может быть проинтерпретировано как безобидная шутка, а другой - как серьёзная угроза.

\section{Ключевые слова}

подшучивание; дискурс; политика; США; Трамп; шутка; сарказм; интерпретация; поляризация; прайминг 


\section{Чувство юмора Трампа: обманчивая спонтанность}

В США не утихают споры о том, есть ли у Дональда Трампа чувство юмора ${ }^{1}$. Некоторые говорят, что есть - ведь он смеётся; однако, как известно, смех - сложное явление. Человек, играющий на публику, вероятно, хорошо умеет ее рассмешить, когда того требует конкретное представление; как мы вполне обоснованно можем предположить, Трамп с его полученным ранее опытом общения с репортёрами нью-йоркских новостных таблоидов, работы в области имиджевой рекламы, связанной с использованием своего имени для продвижения элитной недвижимости и товаров, и успехом в роли звезды телевизионного реалити-шоу. Если актёру известно, что американцы ценят хорошее чувство юмора, то он, скорее всего, захочет его продемонстрировать.

Как отмечают наблюдатели, мы никогда не видели, чтобы Трамп по-настоящему самозабвенно, от души смеялся (что, например, случалось с Хиллари Клинтон). Сейван (Savan, 2016) рассмотрела все примеры выступлений, во время которых публике хотели показать смеющегося Трампа, и пришла к выводу, что тот искренне рассмеялся лишь однажды, во время встречи с избирателями, когда раздался звук, напоминающий собачий лай, и кто-то из публики крикнул, что это «Хиллари» (намёк на случай, когда Хиллари Клинтон сымитировала собачий лай). Трамп и в самом деле рассмеялся, но при просмотре записи видно, что это, определённо, не смех от души, а скорее его обычный смешок, при котором он открывает рот чуть шире и запрокидывает голову. Однако ни один добросовестный наблюдатель не сочтёт, что Трамп в этот момент смеётся самозабвенно 2 .

Сейван также указывает, что искренний смех - не в характере Трампа. Смеющийся человек, - рассуждает она, - не контролирует ситуацию, а реагирует на совершённое другим действие (а в случае с искренним смехом реагирует невольно). Эта черта соответствует предпочтению Трампа выглядеть настоящим мужчиной, контролирующим ситуациюㅇ.

1 Официальное заявление члена администрации Трампа о том, что президент обладает «прекрасным чувством юмора», см. Parker (2017). Рассуждения писателя-комика о чувстве юмора Трампа см. Scovell (2018).

2 Следует также отметить, что в американском английском назвать женщину собакой значит крайне её унизить: речь идёт не только о возможной аллюзии на ругательство «сучка» (bitch), но, прежде всего, на подразумеваемое таким сравнением невероятное уродство.

3 Фогель (Vogel, 2015) описывает кризис американской маскулинности в эпоху Рейгана, проявившийся в том числе в отрицательной реакции на образ «кроткого» мужчины, который стал женственным (одомашненным, выхолощенным) и призыв вернуться к «настоящему мужчине - мужчине, вновь обретающему “глубинную мужественность”, приличествующий воину склад ума, потерянный культурой, сложившейся в результате борьбы за гражданские права». Если лозунг Трампа - «Вернём Америке былое величие!» - отсылает к этому историческому периоду, то можно рассматривать его амплуа как попытку воплощения этого мужественного образа. 


\section{Чувство юмора Дональда Трампа: в соответствии со сценарием}

Я выделила два типа заранее подготовленных шуток Трампа и выбрала по одному примеру на каждый. Первый из примеров относится к октябрю 2016 года, когда прямо перед выборами Трамп присутствовал на благотворительном ужине мемориального фонда Альфреда Смита в Нью-Йорке'.

Фоном для этого выступления стала речь Мелании Трамп, произнесённая во время национального съезда республиканской партии: некоторое время её наперебой расхваливали, пока не обнаружили с помощью программ для определения плагиата, что существенные фрагменты этой речи совпадали с текстом более раннего выступления Мишель Обамы.

(Трамп смотрит на лист с текстом и затем говорит не по сценарию): Ох, и попаду же я из-за этого в неприятности.

\section{(Смех)}

Не из-за Хиллари. [С этого момента он зачитывает текст по бумажке:] Знаете, президент посоветовал мне перестать хныкать, но, должен сказать, что в этом году СМИ предвзяты, как никогда. Хотите доказательств? Мишель Обама произносит речь, и она всем нравится - замечательно. Все думают, что речь великолепна. Моя жена, Мелания, произносит в точности ту же речь...

(Смех)

- и от неё всё никак не отвяжутся.

\section{(Аплодисменты)}

Я не понимаю, в чём тут дело.

\section{(Аплодисменты)}

[с этого момента и до самого конца он говорит не по бумажке] И в этом нет её вины. Встань, Мелания. Поднимись же. Её постоянно оскорбляют.

\section{(Аплодисменты)}

Ox, и не поздоровится же мне сегодня дома. Я... она об этом не знала. [Поворачивается к Мелании] Мне не поздоровится? Или ничего, всё в порядке?

Кардинал, пожалуйста, побеседуйте с ней.

(Смех)

В этом случае Трамп упоминает о компрометирующем его жену инциденте, а затем ухитряется одновременно высмеять её и выставить жертвой (по всей видимости, «оскорблений» критиков и журналистов), хотя именно она и произнесла злополучную речь, а затем заявляет, будто не понимает, в чём дело.

1 Благотворительный ужин мемориального фонда Альфреда Смита - это ежегодное событие в честь знаменитого мэра Нью-Йорка, во время которого собираются средства для различных католических благотворительных фондов нью-йоркской архиепархии, оказывающих помощь детям. Поэтому в конце выступления Трамп обращается к кардиналу. 
Вторая шутка прозвучала в 2018 году, во время ежегодного ужина Гридирон-клуба в Вашингтоне, округ Колумбия 1 .

\begin{abstract}
Я знаю, что Гридирон- старинная традиция в Вашингтоне, очень давняя и важная для многих из вас, журналистов. Поэтому я с восторгом принял приглашение и явился сюда, чтобы лично испортить вам вечер... с приближением этого ужина в моей администрации занервничали, опасаясь, что я неспособен к самоиронии. Они из-за этого переживали, спрашивали: «У Вас получится?» И я им сказал не переживать. Когда дело доходит до самоиронии, мне нет равных... Вообще-то Оррин Хэтч, Оррин сказал: «В истории Америки не было ещё человека с более тонким чувством самоиронии, чем Дональд Трамп - он превосходит и Вашингтона, и Линкольна...» Спасибо, Оррин.
\end{abstract}

В данном случае Трамп заявляет, что способен испортить вечер, важный для журналистов, которых он постоянно называет своими врагами. Затем он зачитывает хвастливую шутку о самоиронии, а следом - ещё одну, преувеличенную, попутно оскорбив поддерживавшего президента и выставив подхалимом своего сенатора, которого он выставил подхалимом.

С точки зрения современной психологической теории адаптивного/ дезадаптивного юмора, изложенной Мартином (Martin, 2003), юмор Трампа попадает в категорию «дезадаптивного», то есть нацеленного на выражение агрессии и превознесения самого себя за счёт остальных. Юмор подобного стиля соответствует культивируемому Трампом образу «настоящего мужчины» ${ }^{2}$. С самого начала своей политической кампании Трамп играл роль не связанного с политическими кругами аутсайдера, который может разрушить сложившийся в современной политике status quo коррумпированного правительства, неспособного функционировать нормально. Это совпадает с его представлениями о мире как об опасном месте, где постоянно идёт борьба, где есть победители и проигравшие, и где он сражается за интересы своих сторонников. Это также соответствует стратегии «разговора начистоту» (ассоциирующейся одновременно с рядовыми избирателями и презрительным отношением к «политкорректности»), которую некоторые аналитики (Sclafani, 2016; Theye \& Melling, 2018) представляли основной причиной, почему сторонники Трампа считают его не только «самобытным» человеком, но и сильным лидером.

\title{
Материал исследования
}

Известно множество высказываний Трампа, характеризуемых как «несерьёзные» (Rieger, 2019). Чтобы не превышать заявленный объём статьи, я выбрала три примера таких высказываний, которые сам Трамп, Белый Дом или сторонники президента называют несерьёзными (балагурством, подтруни-

1 Ужин Гридирон-клуба устраивается престижной организацией журналистов: его участники жертвуют на стипендиальные программы. Ожидается, что речи, произносимые политиками во время этого события, будут полны самоиронии.

2 См. Parker (2017) о коммуникационном стиле Трампа в Белом доме. 
ванием, сарказмом, шуткой), а противники президента восприняли отрицательно. Критический разбор этих трёх примеров демонстрирует многообразие способов восприятия Трампа как угрозы. В двух случаях дискурсивным свидетельством того, что эти заявления не следует интерпретировать как нечто, сказанное всерьёз, является зафиксированный на видеозаписи или в расшифровке смех, которым реагирует на слова непосредственная аудитория. Как будет отмечено ниже, в каждом случае природа данных несколько отличается. Возможно, самый знаменитый пример взят из пресс-конференции, где отсутствует указание на немедленную реакцию присутствующих представителей прессы1. В том случае, когда доступна видеозапись, я расшифровала её сама. Для каждого примера я собрала свидетельства того, что слова были произнесены «в шутку»: от Белого дома и сторонников президента, а также в одном случае, - письменное свидетельство самого Трампа. Также я собрала для каждого примера варианты интерпретации сказанного журналистами и общественными деятелями, выступающими как в поддержку Трампа, так и против него.

\section{Теоретическая трактовка стратегии «это всего лишь / просто шутка»}

Если говорить о теоретической интерпретации стратегии «это всего лишь/просто шутка», то начинать следует с Бейтсона (Bateson, 1972) и метакоммуникативной функции того, что в своём классическом исследовании выдр из зоопарка Сан-Франциско Бейтсон назвал «сообщение это игра». Иными словами, сообщение, которое, на первый взгляд, передаётся (то есть, в случае выдр, «мы с тобой дерёмся»), опровергается подтекстом «это игра». В общении между людьми существует вербальное высказывание и невербальный подтекст, показывающий, что высказывание не следует воспринимать всерьёз. Если всё идёт так, как задумал говорящий, то собеседник немедленно ответит на сказанное смехом или иным типичным образом. Однако если что-то пойдёт не так, то говорящий может заявить, что он/она шутит или «всего лишь шутит» (only joking). В американском английском это классическая стратегия в межличностном общении, позволяющая убедительно отречься от своих слов и включающая минимизаторы - «просто» (only) или изящно аллитерирующее «всего лишь» (just). Синонимичный, но, возможно, чуть менее формальный вариант этого выражения - «всего лишь/только подтрунивание» (just/only kidding) $)^{2}$ В американском английском наиболее распространённой функцией

1 Я не пыталась анализировать невербальное поведение Трампа с точки зрения намёков на то, что речь была несерьёзной, но, скорее, использовала реакцию аудитории как показатель того, поняла ли аудитория, что в тот момент он хотел пошутить. Это было проблематично лишь в случае заявления «Россия, если вы слушаете...» - но, как я указываю, в докладе Мюллера Трамп письменно засвидетельствовал своё намерение пошутить.

2 Первое появление слова, связанного с понятием kidding (подтрунивание) Oxford English Dictionary относится к 1873 году (Slang Dictionary): «Вопрос No kid, now? часто задаётся тем, кто подозревает, что его 
выражения "всего лишь подтрунивать" является защита говорящего от любой предвидимой негативной реакции на юмор, который могут счесть плоским, неуместным или оскорбительным (Skalicky, Berger \& Bell, 2015). Здесь мне кажется важным отметить, что говорящий «предвидит» реакцию, что позволяет сократить временной промежуток между высказыванием и оговоркой. В классической ситуации непосредственного общения говорящий внимательно следит за реакцией собеседника и может немедленно пошутить в ответ, если эта реакция не такова, как ожидалось. Ниже я буду называть эту стратегию просто подшучиванием.

В случае выступлений Трампа перед сторонниками, он немедленно видит, как они реагируют на сказанное. Лишь позднее, когда о его высказываниях узнают (и реагируют на них отрицательно) другие аудитории, Белый Дом или его разнообразные политические заместители характеризуют сказанное как шутку. При личном общении в аналогичной ситуации шутник бы неправильно понял реакцию собеседника и объяснил бы, что шутит, позднее, услышав от сторонних наблюдателей или кого-то ещё, что своей шуткой нанёс собеседнику оскорбление. Большинство людей подобное запоздавшее объяснение укрепило бы в подозрении о его неискренности. Если между говорящим и аудиторией существуют посредники, то можно предположить, что люди будут несклонны доверять запоздавшему объяснению, в особенности после того, как Белый Дом отследил реакцию политических оппонентов. В действительности, как пишут Тейе и Меллинг (Theye \& Melling, 2018) Трамп обычно ждёт реакции прессы, и лишь потом заявляет, что просто пошутил; такое поведение аналогично запоздавшему объяснению в обсуждавшейся выше ситуации личного общения ${ }^{1}$.

Мы не можем точно сказать, почему аудитория смеётся (и нам известно, что смех - сложная материя, поскольку может свидетельствовать не только о веселье); однако если судить о восприятии юмора по смеху, можно предположить, что слушатели Трампа считают его замечания смешными. Разумеется, есть и иное объяснение: участники собраний не воспринимают юмор в словах Трампа - они просто являются его убеждёнными сторонниками, и находятся с ним на одной волне. Если это так, можно ожидать, что они будут считывать намёки, позволяющие догадаться, когда Трамп ждёт от них смеха. Хэй (Нау, 2001) называет это явление «смеховой поддержкой» (humor support).

обманывают». Существует этимологическое объяснение (Online Etymological Dictionary), что kid («козлёнок») в сленге семантически распространяется на child («ребёнок»), а затем появляется глагол to kid («обращаться с кем-то как с ребёнком»). Годдар (Goddard, 2018, р. 497) различает вышучивание (joking) и подтрунивание (kidding), подчёркивая в последнем случае связь с обманом (hoax): в отличие от поддразнивания (teasing) подтрунивание «связано с конкретным, достаточно сложным намерением в отношении субъекта и, более того, подразумевает, если воспользоваться неформальным выражением, что собеседнику "морочат голову”».

1 По всей видимости, есть сленговый термин для такой стратегии (Urban Dictionary) с примечательной научной отсылкой: «козёл Шрёдингера» (Schrödinger douchebag) - очевидная аналогия с известной логической проблемой (Thompson, 2016). 
Сложность состоит в том, что ни одно из обсуждаемых ниже высказываний не является смешным в каком-либо традиционном смысле этого слова. Я могу счесть их хоть сколько-то смешными, лишь предположив, что все они представляют собой пример гиперболы настолько радикальной, что говорящий полагает, что аудитория не поверит в то, будто он и в самом деле так думает. Таким образом, люди смеются из-за абсурдности преувеличения. Такие высказывания могли бы укладываться в классификацию (Young et al, 2019), различающую иронию (тип юмора, при котором понимание зависит от того, осознаёт ли слушатель, что говорящий произносит одно, а имеет в виду другое) и преувеличение/гиперболу (недвусмысленный тип юмористического высказывания, когда сообщение выражается в форме преувеличения, буквально). Марш (Marsh, 2018) обсуждает это качество шуток Трампа в терминах абсурдного юмора. Здесь также уместна теории Фрейда (Freud, 1905/1990), поскольку согласно ей шутки (во всяком случае, тенденциозные) выражают то, что в другой ситуации было бы сочтено социально неприемлемым, иными словами - нарушают нормы и выражают запретные желания.

Однако если у «шутливых» обращений Трампа есть всего лишь две основные аудитории (с одной стороны, его сторонники, например, участники собраний избирателей, а с другой - оппоненты), то нам придётся обратиться к Бахтину (Bakhtin, 1981) и введённому им понятию «двухголосия». В отличие от пародийной сатиры Кольбера (Davies, 2018), в которой Кольбер очевидным образом изображает ведущего консервативного ток-шоу, а затем использует гиперболу для создания комического эффекта (и кажется, будто он обращается к консервативной аудитории, для которой, несомненно, его шоу не предназначено, обращаясь, на самом деле, к аудитории, глубоко несогласной с консервативными идеями), Трамп, несомненно, обращается к двум разным аудиториям.

Первой аудитории, своим убеждённым сторонникам, Трамп с его шутливыми высказываниями представляется человеком, в действительности занимающим определённые позиции (например, он просит иностранные государства поддержать его на выборах, игнорирует ограничение срока президентских полномочий) ${ }^{1}$. Как указывает Марш (Marsh, 2018, p. 445): «То, что он - звезда реалити-шоу, усиливает его способность уклоняться от ответственности, ибо мы никогда не можем с уверенностью сказать, искренен ли он или лишь играет на публику; и он самым выгодным образом использует эту двойственность». Это добавляет ещё один уровень опосредования к теории Гоффмана, концептуализирующего повседневную самопрезентацию как спектакль. В данном случае гиперболы нарушают нормы и выражает те мысли, которые, по мнению Трампа, могут понравиться его сторонникам, поскольку позволяют вдохнуть жизнь в образ «настоящего мужчины» как ниспровергателя status quo; смех на встречах с избирателями подтверждает, что он прав в оценке своих

1 Я не вполне понимаю, не выбивается ли из этого ряда заявление о возможности «пристрелить когонибудь на Пятой Авеню»; кажется более вероятным, что эта гипербола символизирует готовность «нарушать правила» - элемент культивируемого им образа сотрясателя устоев. 
сторонников. В отсутствие исследований того, как интерпретируют слова Трампа его сторонники, неясно, какие именно коммуникативные сообщения, замаскированные под шутки, понимает и принимает доброжелательная аудитория. Например, воспринимают ли сторонники Трампа просьбу к России найти электронную переписку Клинтон как законный способ победить на выборах, заручившись поддержкой иной страны?

Перед второй аудиторией, своими противниками, Трамп также выставляет свои взгляды напоказ. Комментарии политических оппонентов Дональда Дж. Трампа показывают, что они зачастую считают его «шутливые» комментарии не только несмешными но и, на самом деле, угрожающими (например: «Я мог бы встать посреди Пятой авеню, выстрелить в кого-нибудь - и не потерять избирателей»). Аудитория, не поддерживающая Трампа (то есть «Другие»), слышит смех первой аудитории, но не понимает, что же «смешного» в произнесённых словах. Высказывания расцениваются как выражение совершенно неприемлемых идей о поведении, приличном для взрослого человека, об уважении к законам и американской конституции и о следовании элементарным нормам и принципам демократического общества. Если бы эти заявления делал кто-то, чьим мнением легко пренебречь, это не вызвало бы такой тревоги, но оппонентов чрезвычайно настораживает, что подобные высказывания принадлежат президенту Соединённых Штатов, чьё поведение должно бы быть образцовым, кто является главой исполнительной ветви власти и главнокомандующим вооружёнными силами, и кто поклялся защищать конституцию Соединённых Штатов. Аудитория президента беспрецедентно широка он выступает с высокой трибуны. Больше всего пугает то, что в результате когнитивного процесса актуализации установки слова Трампа «нормализуют» его стиль и высказываемые им неприемлемые идеи.

Однако Трамп также стремится вызвать своими очевидными гиперболами возмущение в стане врага. Как отмечает Марш (Marsh, 2018) и как заключаю я в данной статье, подстрекательство оппонентов к обличающим заявлениям оказывается элементом дискурсивной игры. Как я постараюсь объяснить при обсуждении примеров, в различных шутливых замечаниях существует множество слоёв потенциально передаваемого смысла.

С точки зрения социальной функции юмора, очень важной оказывается отождествление с группами «Мы» и «Другие». Марш (2018) обращает наше внимание на статью Файна и Де Суси в журнале Humor (Fine \& De Soucey's, 2005) о культурах шутки, где речь идёт о юмористических темах как методе социальной регуляции жизни группы. Я также обращаюсь к твитам Стида (Wade, 2016: August 10). Группа «Мы», образуемая сторонниками Трампа во время его выступлений, участвует в юмористической коммуникации, чтобы сформировать групповую идентичность и усвоить идеи, содержащиеся в предположительно абсурдных утверждениях. Вероятно, гипербола их смешит, но идеи они усваивают. Единственной аудиторией для шутливых заявлений 
являются «Другие», оппоненты, которые, предположительно, не хотят разделять выражаемые в шутках идеи группы «Мы».

Как известно, попытки поставить эти высказывания под вопрос отметаются с помощью классического метода ухода от ответственности, и Бейтсон помогает это понять: Трамп всего лишь шутит ${ }^{1}$. Типичный следующий ход, который можно совершить, будет метакоммуникативным: вам, оппонентам Трампа, не помешало бы обзавестись чувством юмора (Ruiz, 2017). В американском обществе это очень обидное замечание, прекрасно отвлекающее внимание от критики, поскольку тем самым оппонента пренебрежительно называют не только раздражающим членом группы «Других», но также, возможно, человеком недостаточно умным и утончённым, чтобы оценить шутку. Таким образом, то, что Белый Дом и его сторонники списывают со счетов как шутки, противники Трампа интерпретируют как внушающую беспокойство стратегию, используемую в общественном дискурсе и нормализирующую общение, нарушающее важные для демократического общества нормы.

\section{Примеры}

Ниже я рассмотрю три «шутки» Дональда Трампа (в хронологической последовательности, с начала его президентской кампании, и уделяя особое внимание предположительно спонтанным высказываниям) и проанализирую их с точки зрения сопряжения юмора с угрозой.

\section{Пример 1: «я мог бы встать посреди пятой авеню, выстрелить в кого-нибудь - и не потерять избирателей»}

Это было сказано 23 января 2016 года, во время предвыборного выступления в Айове:

Мои сторонники очень умны. А знаете, что ещё говорят о моих сторонниках? Опросы. Из них ясно, что они - беззаветно преданны. Вы когда-нибудь такое видели? Я мог бы встать посреди Пятой авеню, выстрелить в кого-нибудь [выбрасывает палец, изображая, что стреляет] - и не потерять избирателей, так? Это, вообще, невероятно. [Смех в зале. ПРИМ: Трамп не смеётся.] Они говорят [выкрик из зала: «Мы любим тебя»]. Мы тебя тоже любим. (Видеоклип CNN).

\section{Реакция Трампа / Белого дома / сторонников президента}

25 января 2016 года Трамп дал интервью Вольфу Блитцеру на CNN:

ВБ: У вас очень преданные сторонники.

дт: Это так.

ВБ: Я думаю, на самом деле вы... думаю, вы пошутили, сказав... это вызвало много шума. Вы сказали, что могли бы встать посреди Пятой авеню, выстрелить в кого-нибудь, и это не повлияло бы на поддержку ваших избирателей.

1 Объяснение того, как это работает в рамках теории вежливости Браун и Левинсона (Brown \& Levinson, 1987), cM. Davies (2006). 
ДТ: Ну, вы не думаете, что я пошутил - вы это знаете. Разумеется, я шутил. Весь зал смеялся, и я смеялся, когда говорил это.

ВБ: Поскольку, знаете ли, вас критикуют.

Дт: Нет, не критикуют - это всё лживая пресса. Они заявляют: «Ой, он что-то сказал». Потом показывают меня, я смеюсь, они смеются, все смеются и отлично проводят время. Разумеется, я шутил. Вы это знаете. Но цель этого - показать, что люди меня любят, знаете, и хотят и дальше меня поддерживать: они устали смотреть, как страной помыкают и управляют глупцы. Они устали от этого, Вольф...

Ведущая Fox Business News Мария Бартиромо во время интервью спросила Трампа об этом комментарии, и он ответил: «Мы все забавлялись. И мне время от времени нравится быть слегка неполиткорректным. Ничего плохого в этом нет» (Jerde, 2016). ABC News (Gittleson, 2016) назвали этот комментарий «шутливым» и сообщили, что «студент-волонтёр кампании Трампа, присутствовавший на предвыборном митинге, сказал, что смысл был ясен - Трамп сохранит сторонников, что бы о нём не говорили журналисты, другие кандидаты и агитация противников».

\section{Реакция оппонентов}

В редакторской колонке TV Guide (Mathews, 2016), содержащей комментарий и цитаты из сатирических «Известий выходного дня», части телешоу Saturday Night Live, отражены основные тезисы оппонентов Трампа: «Очевидно, это не серьёзное заявление, но оно, тем не менее, неуместно, ибо президент должен хотя бы делать вид, что не относится к убийству легкомысленно. Комментарий Трампа быстро осудили. Колин Джост на SNL обратился к нему со следующими словами: "Что за дела, приятель? Ты хвастаешься, что твои сторонники так тебя любят, что ты можешь без опасений убить когонибудь забавы ради? Тебе ведь известно, что президенты так не делают? Ты же не президент из «Голодных игр»". “Дональд, ты обращаешься к самым безумным людям в стране", - добавил Майкл Че». Во время процитированного выше интервью Fox Business News ведущая сопроводила вопрос замечанием, что за последнее время в США произошло несколько массовых убийств, тем самым недвусмысленно осудив неуместность заявления.

\section{Обсуждение}

Трамп и его сторонники не сомневаются, что заявление не было серьёзным. Смех и веселье являются ценностью - так преподносят слова Трампа. Их буквальное значение полностью скидывают со счетов и воспринимают только как гиперболу, порождающую «шутку». Никто не говорит, что Трамп никогда бы не повёл себя таким образом, но подразумевается, что это очевидно. Трамп ясно понимает, что сказал что-то неуместное, поскольку отмечает, что был «слегка неполиткорректен»; эти нарушения норм общественной дискуссии позволяют ему носить столь ценимую его сторонниками маску ниспровергателя авторитетов. Его стиль льёт воду на мельницу реакцио- 
неров, выступающих против предпринимавшихся в последние десятилетия попыток относиться к используемым словам с большей осторожностью и чаще проявлять уважение к чувствам всех существующих в США групп, не принадлежащих к классам, долгое время стоявшим у кормила власти (иными словами, избегать мизогинии, расизма, гомофобии и т. д.). Декларируемая Трампом «цель» - продемонстрировать, что он пользуется любовью сторонников, которые не отрекутся от своего кандидата (подразумевается, отчасти потому, что в отличие от предыдущих лидеров он не «глупец»). Как ясно даёт понять студент-волонтёр, сторонники сохранят верность и невосприимчивость к критике в адрес Трампа, каким бы ни был её источник. Предположительно, ещё одно послание для сторонников - то, что Трамп в высшей степени их одобряет, воздавая высокие похвалы их верности - качеству, которое, кажется, он очень ценит.

Для противников Трампа у его слов есть несколько возможных значений. Если следовать за приведёнными выше комментариями, оппоненты признают, что Трамп говорил не всерьёз, но порицают подтекст основного заявления: шутить об убийстве неправильно. Критики переходят от использованного Трампом слова - shoot (которое может означать «убить», а может и не иметь такого значения, и которое используется в том числе и в совершенно невинных контекстах, например: When you get a chance, shoot me an email) к словам, делающим более очевидными жестокость, связанную с заявлением о возможности «в кого-нибудь выстрелить» (shooting someone). Напряжение возрастает по мере того, как от сравнительно нейтрального слова kill противники Трампа переходят к термину murder, используемому в юриспруденции для обозначения незаконного намеренного убийства одного человека другим. Ведущий Saturday Night Live Колин Джост намекает на гиперболический подтекст («убить кого-нибудь забавы ради») и использует отсылку к произведению массовой культуры (жестокой дистопии «Голодных игр»). Замечание Майкла Че свидетельствует об иной тревоге оппонентов Трампа: что крайняя преданность его сторонников проблематична, если она приводит к мысли, будто Трамп выше закона, или к восприятию его слов как нормализации насилия (если не подстрекательство к нему). Для противников Трампа всё это слишком похоже на криминального авторитета. Интервью Fox Business News подспудно порицает Трампа за шутку о вооружённом насилии, прозвучавшую вскоре после нескольких массовых убийств в США.

Это высказывание дважды повторялось в октябре 2019 года в федеральном апелляционном суде при рассмотрении дела о том, имеет ли президент Трамп право препятствовать государственной прокуратуре Нью-Йорка, пытающейся вызвать его в суд для обсуждения налоговой отчётности. Адвокаты Трампа утверждали, что он не подлежит уголовному преследованию иными словами, что он стоит выше закона. Вайзер и Пайбарах (Weiser \& Paybarah, 2019) сообщают, что «Кэри Р. Данн, главный юридический советник 
прокурора округа Манхэттен, процитировал знаменитое заявление президента, будто он может выстрелить в кого-нибудь посреди Пятой авеню, не потеряв политической поддержки». Из приведённой ниже цитаты ясно, что прокурор Данн процитировал слова Трампа, задавая риторический вопрос, тогда как судья адресовал его непосредственно адвокату Трампа. «Мистер Данн спросил, что произойдёт в самом крайнем случае. "Следует ли нам ждать начала процедуры импичмента?" - спросил он. Затем судья Денни Чин, спросил мнение адвоката мистера Трампа, Уильяма С. Консовоя, о гипотетической стрельбе на Пятой авеню. "Местные власти не смогли бы начать расследование? Они ничего не смогли бы поделать в подобной ситуации?" - спросил судья Чин, повторяя: “Совсем ничего? Вы так считаете?” “Да, так. Именно так”, ответил мистер Консовой».

\section{Пример 2: «Россия, если вы слушаете - надеюсь, вы сможете отыскать 30000 пропавших электронных писем»}

Эти слова были произнесены на пресс-конференции 27 июля 2016 года. На сделанной C-SPAN видеозаписи не слышно никакой реакции аудитории и в кадре был только Трамп, без журналистов; потому визуальные свидетельства об их реакции отсутствуют. Контекст таков: Трампа спросили о взломе компьютерной сети Национального комитета демократической партии. В своём ответе он заявил, что никак не связан с Путиным (несмотря на сведения, что в то время он активно стремился построить Башню Трампа в Москве), что, вероятно, это были не русские, но если это и так - он надеется, что хакерам удалось взломать электронную переписку Клинтон за то время, когда она была государственным секретарём. Во время предвыборной кампании Трампа уязвимость сервера электронной почты Клинтон постоянно была на острие атаки.

Я скажу вам так: Россия, если вы слушаете - надеюсь, вы сможете отыскать 30000 пропавших электронных писем. Я думаю, наша пресса вас щедро за это вознаградит.

\section{Реакция Трампа / Белого дома / сторонников президента}

Как отмечалось выше, из видеозаписи неясно, смеялись ли представители прессы, но на следующий день последовали заявления о несерьёзности сказанного (Blake, 2016). В ходе интервью на утреннем шоу Fox and Friends, Трамп отмёл утверждение интервьюера, что дело касается «национальной безопасности», и заявил, что на пресс-конференции о был «саркастичен».

Брайан Килмид: Руководители кампании Клинтон заявляют, что речь идёт о национальной безопасности. Если представить, что любой американец призывает иностранную державу развернуть в США шпионскую операцию, чтобы както изменить результаты голосования - думаю, мы вступаем в область национальной безопасности. Что скажете? 
Tрамп: Вы, должно быть, шутите. Его клиент, его человек незаконно удаляет 33000 электронных писем. Вы за этим наблюдаете. А когда я позволяю себе сарказм...

Килмид: А это был сарказм?

Трамп: Разумеется, это был сарказм. Но 33000 электронных писем были удалены, и настоящая проблема в том, что говорилось в этих письмах Национального комитета демократической партии...

Затем Блейк (2016) сообщает, что несколько позднее на CNN приспешник Трампа и бывший мэр Нью-Йорка Руди Джулиани объяснил «шутку»: «Нет. Он шутил. Выйдя из самолёта, он твитнул, что электронные письма следует отослать в ФБР. Он просто валял дурака».

В случае этого заявления последовала серия отложенных реакций, к которым я обращусь после того, как опишу немедленную реакцию противников Трампа.

\section{Реакция противников}

Изначально возмущение было выражено в двух выступлениях оппонентов Трампа. Грэхем (Graham, 2016) следующим образом прокомментировал его заявление в Atlantic Magazine: «То был шокирующий момент: кандидат в президенты призывает иностранную державу не просто взломать почту его оппонентки и обнародовать найденное, но выражает надежду на кражу русскими электронной переписки американской чиновницы высшего ранга - переписки, возможно, содержащей засекреченную информацию». В этой статье не упоминается о возможности того, что Трамп шутил. Второй отклик появился в выпуске Media Matters от 27 июля и включал стенограмму заявления, полученного телепрограммой CNN At This Hour with Berman and Bolduan от политического обозревателя CNN Дэвида Грегори: «Если честно, мне не хватает слов, чтобы выразить, как я шокирован, и насколько неприемлем тот факт, что Дональд Трамп является потенциальным лидером свободного мира, главнокомандующим нашей страны. Это воистину неприемлемо. Он призывает Россию, которая, судя по всему, стояла за утечками в одной из наших главных политических партий, не останавливаться на достигнутом, продолжить начатое и попробовать взломать сервер Хиллари Клинтон, чтобы найти пропавшие письма, стать, так сказать, центральной фигурой скандала. Он похож на играющего со спичками ребёнка, который не понимает, насколько сильно он сам и вся страна может обжечься. Дело очень серьёзно. И, думается мне, для Трампа характерно то, что он весь - как на ладони. Он очень ясно даёт понять, что думает, как получает информацию, и, честно говоря, мне кажется, что отсутствие серьёзности и несдержанность, с которыми он высказывается о важных проблемах национальной безопасности, определённо должны настораживать». Грегори ссылается на «отсутствие серьёзности и несдержанность», которые я бы лексикализировала как «легкомысленный», и, возможно, именно это Трамп имел в виду по «сарказмом». 


\section{Отложенная реакция Трампа и его сторонников}

В свете дальнейших открытий относительно действий России (не последним из которых было открытие, что позднее в тот же день, когда прозвучали слова Трампа, русские хакеры атаковали почтовый сервер Клинтон) откровенное высказывание Трампа привело к новым отложенным реакциям Трампа и его сторонников. По сообщению Смита (Smith, 2018), в марте следующего года бывший секретарь Белого дома Шон Спайсер сказал, что Трамп просто пошутил, когда во время предвыборной кампании просил Россию «отыскать 30000 пропавших писем» Хиллари Клинтон, кандидатки в президенты от демократической партии. «В тот раз он пошутил», - сказал Спайсер, - «мы все это знаем». В августе следующего года популярный американский карикатурист откликнулся на авторскую колонку в New York Times Джона Бреннана, занимавшего пост директора ЦРУ в 2013-2017 годах. Бреннан заявил: «И без того сложная работа американской разведки и правоохранительных органов стала ещё сложнее в июле 2016 года, когда кандидат в президенты, мистер Трамп, публично призвал Россию отыскать пропавшие электронные письма миссис Клинтон. Этим заявлением мистер Трамп не только поощрил иностранную державу к получению разведданных о гражданке Соединённых Штатов, но и открыто разрешил своим сторонникам сотрудничать с нашим основным глобальным противником, выступая против его политической оппонентки». Отклик карикатуриста (цит.: Mikelionis, 2018) был таков: «Итак, Бреннан, возможно, объявил одну из важнейших в истории политических охот на ведьм потому, что не понял шутки - и я это даже не выдумываю».

Позднее в том же году (20 ноября 2018 года) президент Трамп представил письменные ответы на вопросы, поставленные в расследовании Роберта Мюллера. Обнародованный 18 апреля 2019 года доклад Мюллера включает следующее примечание:

Пресс-конференция Дональда Трампа, Дорал, Флорида, C-SPAN (27 июля 2016). Через пять часов после заявления Трампа российская разведывательная служба начала проверять возможность взлома почтовых аккаунтов, связанных с Хиллари Клинтон. См. T. 1, раздел III, выше. В письменных ответах, представленных в ходе этого расследования, президент утверждал, что сделал заявление «Россия, если вы слушаете» «в шутку и саркастически, что очевидно любому непредвзятому наблюдателю». Письменный ответ Дональда Дж. Трампа (20 ноября 2018) на 13 (ответ на Вопрос II, часть (d)).

В следующем 2019 году, 2 марта, Трамп выступил перед доброжелательно настроенной аудиторией, СРАС (Конференция консервативного политического действия). Иган сообщила (Egan, 2019), что Трамп «насмешливым тоном» произнёс следующие слова: «Благодаря фейк-ньюс я узнал, что если вы шутите, если вы саркастичны, если вам и вашим слушателям весело, если по телевизору за вашим выступлением в прямом эфире наблюдают миллионы, а на стадионе, где вы выступаете, собралось 25000 человек, и если вы говорит нечто вроде: "Русские, пожалуйста, если можете, достаньте нам письма 
Хиллари Клинтон. Пожалуйста, Россия, пожалуйста! Пожалуйста, найдите нам письма! Пожалуйста-пожалуйста!"».

\section{Обсуждение}

Мне неясна изначальная интерпретация сообщения Трампа его сторонниками, хотя даже на этой стадии кампании Трамп никогда не критиковал Путина и с очевидным восхищением относился к авторитарным лидерам мужского пола. Складывается впечатление, что Трамп приветствует помощь России в ниспровержении его оппонентки, Хиллари Клинтон, через обнародование писем, украденных русскими хакерами. Трамп размывает границу между проводимым оппозицией расследованием внутренних американских политических кампаний (что законно) и получением информации от иностранных правительств (что незаконно). Из его публичных просьб можно заключить, что такая помощь кажется ему желанной и нормальной ${ }^{1}$. Ещё одно передаваемое сообщение, связанное со свойствами характера Трампа, вызывающими восхищение у его сторонников, может состоять в том, что Трамп - боец и для победы готов на всё.

Трамп дважды назвал свои слова «саркастическими». Обсуждая сарказм эпохи Трампа, Оконски (Okonski, 2017) приходит к выводу, что Трамп не использует сарказм в традиционном смысле слова; скорее, он прибегает к принципу отчуждения, чтобы, столкнувшись с противниками, заявить, что говорил не в буквальном смысле, одновременно убеждая своих сторонников в том, что сказал именно то, что сказал.

Для оппонентов Трампа это - ещё одно подтверждение неприемлемого сотрудничество Трампа с Россией. Не все оппоненты могут в точности понимать, насколько незаконно получать помощь от иностранного государства в борьбе с соотечественницей и политической оппоненткой, но они чувствуют, что это неправильно. Как множество американцев недавно узнало из выступлений в средствах массовой информации историков и специалистов по конституционному праву, именно это больше всего тревожило авторов Конституции в XVIII веке. Они опасались, что иностранное вмешательство во внутригосударственные политические процессы может сделать выборы подконтрольными, тем самым, по сути дела, упразднив демократию. Сегодня тревогу вызывает то, чего не могли в точности предвидеть авторы Конституции: попытки скомпрометировать демократию как систему управления, предпринимаемые авторитарными режимами, умело использующими высокие технологии. Помимо прочего, они могут достичь этого, настроив друг против друга электорат и заведя правительство в очевидный политический тупик.

\section{Пример 3: «Теперь он - президент до конца жизни...»}

Это было произнесено 3 марта 2018 года, во время импровизированного обращения к финансовым донорам республиканцев в Мар-а-Лаго, принадле-

1 Теперь, из доклада Мюллера, мы знаем, что уже через несколько часов после заявления Трампа русские разведчики начали выполнять его просьбу. 
жащем Трампу курортном комплексе во Флориде. Согласно CNN (Liptak, 2018): «В сделанном за закрытыми дверями заявлении, запись которого была получена CNN, Трамп также похвалил председателя КНР Си Цзиньпина, который недавно укрепил свою власть и продлил срок потенциального правления. При этом он задумчиво сообщил, что и сам не отказался бы от подобного манёвра. Это заявление, произнесённое в бальном зале резиденции Мар-а-Лаго во время обеда и сбора пожертвований, было оптимистичным, пространным, сдобренным шутками и смехом».

[Моя стенограмма аудиозаписи, обнародованной CNN] [?] превосходно. А Си - отличный... господин.

Теперь он - президент до конца жизни.

[Смех, аплодисменты, одобрительные возгласы толпы]

До конца жизни.

\section{[Снова смех, аплодисменты, ликующие крики]}

Нет, он молодец. Посмотрите, ему это удалось. Я думаю, он молодец. Может быть, однажды и нам придётся попробовать.

\section{[Смех, аплодисменты, одобрительные возгласы толпы]}

Он - самый могущественный... президент Китая за последние сто лет... ну, знаете, человек, за сто лет, в Китае, и он был ужасно предупредителен, когда я туда ездил.

\section{Реакция Трампа / Белого дома / сторонников президента}

Хайнс (Hains, 2018) сообщает о следующем обмене репликами в передаче Fox and Friends:

Послушайте, что говорит президент, и представьте, как на это отреагируют так называемые ведущие средства массовой информации... «Он шутил... вы слышите смех в зале». Рэйчел Кампос-Даффи перекрикивает его: «Это шутка! Шутка! Президенту нравиться постоянно развлекать публику. Он создаёт вокруг себя атмосферу веселья, он любит играть на публику». «Но, по иронии судьбы», - добавила она, - «Левые вечно заводят разговор о диктатуре, так? Вечно они талдычат по поводу Трампа: диктатура - то, диктатура - сё. Будет ли диктатор децентрализовать правительство? Будет ли он упразднять нормы федерального права? Вернёт ли он власть людям? Этот президент - противоположность диктатору».

Консервативный интернет-ресурс (Caruso, 2018) сообщил, что «в субботу на частном приёме для финансовых доноров республиканской партии в Мара-Лаго президент Трамп пошутил о пожизненном президентском сроке».

\section{Реакция противников}

Макс Бут (Boot, 2018), бывший консерватор и республиканец, ставший основным критиком Трампа, саркастически отметил: «Например, в субботу Трамп похвалил председателя КНР Си Цзиньпина, сделавшего свои полномочия бессрочными, сказав: “Теперь он - президент до конца жизни... думаю, 
это превосходно. Может быть, однажды и нам придётся попробовать.. Его приверженцы немедленно отмахнулись от этих слов, объявив их забавной остротой. Значит, Трамп не питает никаких авторитарных побуждений? Оставьте надежды на это!» Перле (Perlez, 2018) передает слова политолога Яши Моунка, заметившего, что «у Дональда Трампа есть странная привычка совершенно искренне говорить о самых глубоких своих желаниях, несмотря на длинный перечень его ложных и сбивающих с толку высказываний. Не следует воспринимать его шутку как заявление о намерениях, но, бесспорно, нужно воспринимать её как свидетельство его глубокого восхищения диктаторами наподобие Си Цзиньпина и того, что при случае идея воспроизвести какие-то из их репрессивных политических решений покажется ему соблазнительной».

Ha Vox (сайте, специализирующемся на «разъяснении» политических событий) Стюарт (Stewart, 2018) отметила, что

«эти слова были произнесены во время обеда, на котором происходил сбор средств, и, вероятно, в шутку. Однако американский президент, шутящий о том, чтобы всю жизнь оставаться у власти, очевидно, вызывает некоторое замешательство - особенно тот, чьё восхищение диктаторами общеизвестно». Размышляя о взглядах, скрывающихся за этой шуткой Трампа, Липтак (Liptak, 2018) говорит, что «слова Трампа показывают, что он глубоко возмущён тем, что его действия во время кампании 2016 года остаются предметом расследования, а действия его бывшей противницы, Хиллари Клинтон - нет».

\section{Обсуждение}

Для сторонников, в особенности тех, кто восхищается могущественными лидерами и верит, что у американского президента должно быть больше полномочий в правительстве, это может быть привлекательным идеалом. Для тех, кто считает, что администрация Трампа сражается за них, но что ей мешает Конгресс и судебные органы, это может быть способом отстаивать его повестку. Для тех, кто ценит роль Трампа-«ниспровергателя», это может быть ещё один потенциально привлекательный пример того, как он мог бы изменить конституционный строй.

Оппонентов Трампа тревожит, что он, демонстрирует восхищение авторитарными лидерами и предполагает, что мог бы попытаться стать пожизненным президентом. Всех американцев учат в школе, что во время революции мы сражались против тирании монархии, и что авторы Конституции разработали систему сдержек и противовесов ровно для того, чтобы предотвратить концентрацию власти в руках исполнительной ветви правительства. Многие американцы также помнят о существовании 22-й поправки к Конституции, ограничивающей период президентского правления двумя сроками. 


\section{Заключение}

Сложная неопределенность речи нынешнего президента, усложняемой последующей «шуточной» стратегией, допускает множество интерпретаций. В современном американском политическом контексте сторонники и противники президента считывают совершенно разные послания: для сторонников юмор заключается в преувеличениях, которые совершенно невозможно воспринимать всерьёз; противники хотя и понимают, что преувеличение задумывалось как несерьёзное, но полагают, что подобные высказывания выдают подлинные мысли говорящего о правилах поведения и верховенстве закона в демократическом обществе.

С точки зрения юмористического стиля, все три примера можно рассматривать как «агрессивные и полные хвастовства». В первом случае основное мета-послание заявления состоит в том, что Трамп настолько популярен среди «своих» избирателей, что они сохранили бы верность ему, даже соверши он публично некий очевидно незаконный акт насилия. Альтернативная версия этого заявления такова: «Я мог бы совершить во время кампании все возможные ошибки, и тем не менее не потерял бы ни одного сторонника»; такая формулировка имела бы тот же смысл, но в ней отсутствовало бы агрессивное преувеличение. Во втором примере агрессия направлена на политическую противницу, чью почту говорящий призывает взломать. Самовосхваление можно видеть в очевидной убеждённости Трампа, что у него достаточно влияния, чтобы добиться подобных действий от другого государства. В третьем примере агрессия направлена против американской Конституции, в особенности против 22-й поправки, ограничивающей период президентского правления двумя сроками. Хвастовство можно увидеть в допущении говорящего, будто он будет настолько популярен, что граждане захотят исправить Конституцию, позволив ему стать «пожизненным президентом». Учитывая, что Трамп часто называет свои несерьёзные высказывания «саркастическими», это усиливает их агрессивность, ибо у сарказма есть мишень, которой говорящий намерен повредить. Мета-мишень агрессии во всех трёх примерах - противники президента (которые обычно не являются непосредственной аудиторией его заявлений, а слышат о них позже). Целью правых было вызвать негодование левых, что нашло выражение в устойчивом словосочетании «троллить либералов» (troll the libs). Как отмечает Марш (Marsh, 2018), в намеренно поляризированной обстановке возмущение возрастает из-за убеждённости сторонников Трампа в том, что они не только правы, но и постоянно подвергаются нападкам за свои убеждения. Атаки противников питают их веру в то, что к ним несправедливы. Они отстаивают свои убеждения, а нападки становятся свидетельством их правоты и, без сомнения, делают их менее открытыми к обсуждению иных точек зрения. Согласно удачной формулировке Марш, Трамп «превратил отсутствие смеха в оружие», ибо его противники не только не поддерживают 
его шутки (Billig, 2005), но и отвечают на них яростной критикой, которая кажется сторонникам президента нападением.

Чтобы понять, почему аудитория Трампа смеётся в ответ на его заявления, важно помнить, что ключевой элемент привлекательности Трампа для его сторонников - то, что он ниспровергнет status quo и перетрясёт сверху донизу систему, которая, по всей видимости, работает не на них (но, скорее, на $1 \%$ наиболее богатых граждан и на корпорации). Таким образом, юмористический стиль, постоянно нарушающий границы и посягающий на нормы, вполне логичен. С точки зрения сторонников Трампа, гипербола - всего лишь безвредное преувеличение, соответствующее роли откровенного и подлинного «настоящего мужчины», которую он играет, выступая в качестве защитника своих сторонников. Когда гипербола используется в высказывании: «Услышав, что он это сделал, я так разозлился, что чуть его не убил», - считается само собой разумеющимся, что говорящий не имел это в виду буквально.

Важно также помнить, что с первого дня кампании Дональда Дж. Трампа среди его сторонников были группы тех (возможно, увеличившиеся в последнее время, когда он стал более резким), кому не нравился его стиль, то, какие слова он использует, его бесконечные твиты. Типичным примером было замечание студента, волонтёра кампании Трампа, сказавшего, что тот «вероятно, мог бы выразиться получше» (Gittleson, 2016). Эти сторонники готовы смириться с используемым Трампом оборотами и игнорировать их, поскольку рассматривают его в качестве инструмента, позволяющего достигнуть их целей: снизить налоги, в целом ослабить правительственный контроль, сократить размер государственного аппарата, выйти из кажущихся им невыгодными международных торговых соглашений и, в особенности, ввести в суды больше консервативных судей, чтобы отыграть назад принятые ранее более либеральные решения. Эта группа, скорее всего, согласится с тем, что слова не так уж важны - в противовес тем, кто уверен, что слова, в особенности изрекаемые президентом Соединённых Штатов, оказывают глубокое воздействие. Эта часть сторонников Трампа с большей вероятностью решит, что шутливое заявление следует рассматривать с тех позиций, что слова не нужно принимать «всерьёз», и потому их можно проигнорировать.

С другой стороны, люди, которые крайне отрицательно реагируют на «шутки» Трампа, интерпретируют их как внушающий тревогу приём («стимулирование повторения»), позволяющий ввести в общественную дискуссию и нормализовать идеи, нарушающие важные нормы демократического общества. В частности, в обществе, травмированном массовыми перестрелками, неуместно шутить о том, чтобы кого-то пристрелить. В обществе, выстроенном для защиты от тиранов, опасен очевидный культ личности лидера, якобы стоящего над законом. В демократическом обществе, где авторы Конституции особенно беспокоились об иностранном вмешательстве в выборы, недопустимо в шутку просить авторитарного противника, стремящегося повсеместно вести подрывную деятельность, направленную против демо- 
кратий, помочь победить политическую противницу, одновременно с вами претендующую на президентский пост. Глава федеральной избирательной комиссии недавно недвусмысленно дала это понять: «Комиссия осознаёт "широкий охват" запрета на иностранное содействие и полагает, что даже там, где ценность подобной помощи или услуги "может быть номинальной или с трудом поддающейся определению“, такое содействие, тем не менее, запрещено» (Bublé, 2019). В обществе, в XX веке прошедшем через сложный процесс принятия 22-й поправки к Конституции, ограничивающей период пребывания на посту президента двумя сроками, неприемлемо шутить о пожизненном президентстве (то есть, о том, чтобы стать монархом или диктатором). Если бы дело шло о единичном случае, его можно было бы проигнорировать как незначительный, но оппоненты Трампа рассматривают его поведение как часть последовательной стратегии пренебрежения демократическими нормами и в целом беззакония.

Американцы всегда ценили новшества. Для нашей экономической системы важно «созидательное разрушение», то есть механизм непрерывного обновления изделий и процессов (Schumpeter, 1942). Позиции двух разных аудиторий можно было бы рассмотреть как отражающие творческое напряжение при решении проблемы обновления общества при сохранении ключевых демократических структур. Наша Конституция представляет собой эксперимент, суть которого - показать, как можно создать правительство, сконструированное так, чтобы обеспечить наличие «сдержек и противовесов» власти при верховенстве закона, будучи одновременно открытым для допустимых изменений в ответ на обстоятельства, которых не предвидели авторы Конституции.

\section{Благодарности}

Автор выражает глубокую признательность доценту кафедры английского языка Университета Луизианы Ирине Шпорт за терпение и полезные замечания к переводу статьи.

\section{Список литературы / References}

Bakhtin, M. M. (1981). The Dialogic Imagination: Four essays (M. Holquist, Ed.; C. Emerson \& M. Holquist, Trans.). Austin: University of Texas Press.

Bateson, G. (1972). Steps to an Ecology of Mind: Collected essays in anthropology, psychiatry, evolution, and epistemology. New York: Ballantine Books.

Billig, M. (2005). Laughter and Ridicule: Towards a Social Critique of Humour. London: Sage.

Blake, A. (2016, July 28). Donald Trump's incredible new defense of his Russia-spying-on-Hillary comments: Just kidding! Washington Post. Retrieved from https://www.washingtonpost.com/news/the-fix/wp/2016/07/28/donald-trumpsincredible-new-defense-of-his-russia-spying-on-hillary-comments-just-kidding/ 
Boot, M. (2018, March 7). President Trump's 'jokes' are no laughing matter. Washington Post. Retrieved from https://www.washingtonpost.com/news/global-opinions/wp/2018/03/07/presidenttrumps-jokes-are-no-laughing-matter/

Brennan, J. O. (2018, August 16). President Trump's Claims of No Collusion Are Hogwash. The New York Times. Retrieved from https://www.nytimes.com/2018/08/16/opinion/john-brennantrump-russia-collusion-security-clearance.html

Brown, P., \& Levinson, S. C. (2013). Politeness: Some Universals of Language Usage. Cambridge: Cambridge University Press.

Bublé, C. (2019, September 30). In Act of Defiance, FEC Chair Tweets Memo on Foreign Election Interference Over GOP Commissioner's Objections. Retrieved from Government Executive website: https://www.govexec.com/oversight/2019/09/act-defiance-fec-chair-tweetsmemo-foreign-election-interference-over-gop-commissioners-objections/160248/

Caruso, J. (2018, March 8). Trump Jokes About Becoming 'President For Life' In Private Dinner. Retrieved from The Daily Caller website: https://dailycaller.com/2018/03/04/trumppresident-for-life/

C-SPAN. (2016). Donald Trump on Russia \& missing Hillary Clinton emails (C-SPAN). Retrieved from https://www.youtube.com/watch?v=3kxG8uJUsWU

Davies, C. E. (2006). Gendered sense of humor as expressed through aesthetic typifications. Journal of Pragmatics, 38(1), 96-113. doi: 10.1016/j.pragma.2005.06.006

Davies, C. E. (2018). Satirical news discourse and public pedagogy: Stephen Colbert's "Truthiness". International Round Table: "Social Studies of Humor and Laughter". St-Petersburg, Russia, July 1-5. Presented at the St. Petersburg. St. Petersburg.

Egan, L. (2019, March 3). Trump lets loose at CPAC in longest speech of his presidency. Retrieved from NBC News website: https://www.nbcnews.com/politics/donald-trump/trump-lets-loosecpac-longest-speech-his-presidency-n978556

Fine, G. A., \& Soucey, M. de. (2005). Joking cultures: Humor themes as social regulation in group life. Humor - International Journal of Humor Research, 18(1), 1-22. doi: 10.1515/humr.2005.18.1.1

Freud, S. (1905). Jokes and Their Relation to the Unconscious (The Standard Edition). New York: W. W Norton \& Co.

Gittleson, B. (2016, January 23). Donald Trump Jokes He Could 'Shoot Somebody' Without Losing Support. Retrieved from ABC News website: https://abcnews.go.com/Politics/donaldtrump-jokes-shoot-losing-support/story?id=36474145

Goddard, K. (2018). "Joking, kidding, teasing": Slippery categories for cross-cultural comparison but key words for understanding Anglo conversational humor. Intercultural Pragmatics, 15(4), 487-514. doi: 10.1515/ip-2018-0017

Goldstein, E. B. (2015). Cognitive Psychology: Connecting Mind, Research, and Everyday Experience ( $4^{\text {th }}$ ed.). S.l.: Wadsworth.

Graham, D. A. (2016, July 27). Trump's Plea for Russia to Hack the U.S. Government. Retrieved from The Atlantic website: https://www.theatlantic.com/politics/archive/2016/07/trump-pleas-forrussia-to-hack-classified-american-information/493244/

Hains, T. (2018, March 4). ‘Fox \& Friends' on Trump's President-for-Life Remark: "It's A Joke!" "Take It Figuratively". Retrieved from RealClearPolitics website: https://www.realclearpolitics.com/video/2018/03/04/fox friends on trumps presiden t-for-life_remark_its_a_joke_its_a_joke.html 
Hay, J. (2001). The pragmatics of humor support. Humor - International Journal of Humor Research, 14(1), 55-82. doi: 10.1515/humr.14.1.55

Jerde, S. (2016, January 26). Trump: 'Obviously’ I Was Joking About Shooting People And Not Losing Votes. Retrieved from Talking Points Memo website:

https://talkingpointsmemo.com/livewire/trump-shooting-people-obvious-joke

Kid. (n.d.). Retrieved from Online Etymology Dictionary website: https://www.etymonline.com/ search?q=kid\&ref=searchbar_searchhint

Liptak, K. (2018, March 4). Trump on China's Xi consolidating power: 'Maybe we'll give that a shot some day. Retrieved from CNN website: https://www.cnn.com/2018/03/03/politics/trumpmaralago-remarks/index.html

Marsh, M. (2018). Believe Me, I'm Joking: The Dialectics of the Legend and the Dialectics of Humor. The Journal of American Folklore, 131(522), 444. doi: 10.5406/jamerfolk.131.522.0444

Martin, R. A. (2003). Sense of humor. In S. J. Lopez \& C. R. Snyder (Eds.), Positive psychological assessment: A handbook of models and measures (pp. 313-326). Washington, DC,: American Psychological Association.

Mathews, L. (2016, January 24). Donald Trump Says He Could 'Shoot Somebody' and Not Lose Voters. Retrieved from TVGuide.com website: https://www.tvguide.com/news/donald-trump-icould-shoot-somebody/

Media Matters Staff. (2016, July 27). David Gregory: Trump Suggestion That Russia Hack Clinton's Email Server Is Like "A Child Playing With Matches".

Merica, D. (2017, June 26). Spicer: Trump was 'joking' when he asked Russia to hack Clinton. Retrieved from CNN Politics website: https://www.cnn.com/2017/06/26/politics/trump-clintonrussia-hacking-email-joking/index.html

Mikelionis, L. (2018, August 17). Joke's on Brennan for failing to find humor in Trump's remark, 'Dilbert' cartoonist says [Text.Article]. Retrieved from Fox News website:

https://www.foxnews.com/politics/jokes-on-brennan-for-failing-to-find-humor-intrumps-remark-dilbert-cartoonist-says

Mueller, R. S. (2019). The Mueller Report: Report on the Investigation into Russian Interference in the 2016 Presidential Election. Brooklyn, NY: Melville House Pub.

Okonski, L. (2017). Review: Sarcasm in the Age of Trump Reviewed Work(s): Talk Is Cheap: Sarcasm, Alienation, and the Evolution of Language by John Haiman. The American Journal of Psychology, 130(4), 526. doi: 10.5406/amerjpsyc.130.4.0526

Parker, A. (2017, May 29). Snubs and slights are part of the job in Trump's White House. Washington Post. Retrieved from https://www.washingtonpost.com/politics/snubs-and-slights-are-partof-the-job-in-trumps-white-house/2017/05/29/f5c9d5c0-417a-11e7-9869bac8b446820a story.html

Perlez, J. (2018, March 4). 'President for Life'? Trump's Remarks About Xi Find Fans in China. The New York Times. Retrieved from https://www.nytimes.com/2018/03/04/world/asia/donaldtrump-xi-jinping-term-limits.html

Rieger, J. M. (2016, April 16). 'You don't understand sarcasm': How Trump and his allies downplay his comments. Washington Post. Retrieved from https://www.washingtonpost.com/politics/2019/04/16/you-dont-understand-sarcasmhow-trump-his-allies-downplay-his-comments/ 
Ruiz, D. (2017, October 10). Huckabee Sanders Tells Press to "Get a Sense of Humor," Says Trump was Joking about Tillerson's IQ. Retrieved from Washington Free Beacon website:

https://freebeacon.com/politics/huckabee-sanders-press-sense-of-humor-trump-jokingabout-tillersons-iq/

Savan, L. (2016, September 26). Have You Ever Seen Donald Trump Laugh? The Nation Magazine.

Retrieved from https://www.thenation.com/article/archive/have-you-ever-seen-donaldtrump-laugh/

Schumpeter, J. A. (1942). Capitalism, Socialism, and Democracy. New York: Harper \& Row.

Sclafani, J. (2016, March 25). The Idiolect of Donald Trump. Retrieved from Scientific American Blog Network website: https://blogs.scientificamerican.com/mind-guest-blog/the-idiolect-ofdonald-trump/

Sclafani, J. (2017). Talking Donald Trump: A Sociolinguistic Study of Style, Metadiscourse and Political Identity. Routledge. Retrieved from http://www.myilibrary.com?id=1025963

Scovell, N. (2018, April 28). Opinion | Can Donald Trump Get a Laugh? The New York Times. Retrieved from https://www.nytimes.com/2018/04/28/opinion/donald-trump-jokes-laughs.html

Skalicky, S., Berger, C. M., \& Bell, N. D. (2015). The functions of "just kidding" in American English. Journal of Pragmatics, 85, 18-31. doi: 10.1016/j.pragma.2015.05.024

Smith, A. (2018, February 6). The White House has a favorite excuse to explain away some of Trump's most controversial statements. Retrieved from Business Insider website: https://www.businessinsider.com/trump-joking-excuse-democrats-treason-2018-2

Steed, J. P. (2016). Tweets as cited in Wade (Thesocietypages.org) Aug. 10, with insights from his unpublished diss on the social functions of humor: Joke -making Jews /jokes making Jews: Essays on humor and identity in American Jewish fiction, ProQuest Dissertations Publishing 2004. Retrieved from https://thesocietypages.org/socimages/2016/08/10/humor-theoristexplains-trumps-joke-about-killing-hillary-clinton/

Stewart, E. (2018, March 4). Trump says China's Xi is 'president for life'-And maybe America should try it. Retrieved from Vox website: https://www.vox.com/policy-and-politics/2018/3/4/17077642/trump-xi-china-fundraiser

Theye, K., \& Melling, S. (2018). Total Losers and Bad Hombres: The Political Incorrectness and Perceived Authenticity of Donald J. Trump. Southern Communication Journal, 83(5), 322-337. doi: 10.1080/1041794X.2018.1511747

Thompson, M. (2016, August 27). From Trump to Brexit rhetoric: How today's politicians have got away with words. The Guardian. Retrieved from https://www.theguardian.com/books/2016/aug/27/from-trump-to-brexit-rhetoric-howtodays-politicians-have-got-away-with-words

Trump, D. J. (2016a). Trump on shooting someone: 'Of course I was joking' - CNN Video. Retrieved from https://www.cnn.com/videos/politics/2016/01/25/donald-trump-shoot-someone-loyaljoke-tsr-sot.cnn

Trump, D. J. (2016b, January 23). I Could Stand In the Middle Of Fifth Avenue And Shoot Somebody And I Wouldn't Lose Any Voters. Retrieved from Real Clear Politics website:

http://www.realclearpolitics.com/video/2016/01/23/trump_i_could_stand_in the middl e of fifth avenue and shoot somebody and i wouldnt lose any voters.html 
Urban Dictionary: Schrödinger's Douchebag. (n.d.). Retrieved from Urban Dictionary website: https://www.urbandictionary.com/define.php?term=Schr\%C3\%B6dinger\%27s \%20Douchebag

Vogel, J. (2015). Freaks in the Reagan Era: James Baldwin, the New Pop Cinema, and the American Ideal of Manhood. The Journal of Popular Culture, 48(3), 464-486. doi: 10.1111/jpcu.12278

Weiser, B., \& Paybarah, A. (2019, October 23). If Trump Shoots Someone on 5th Ave., Does He Have Immunity? His Lawyer Says Yes. The New York Times. Retrieved from https://www.nytimes.com/2019/10/23/nyregion/trump-taxes-vance.html

Young, D. G., Bagozzi, B. E., Goldring, A., Poulsen, S., \& Drouin, E. (2019). Psychology, political ideology, and humor appreciation: Why is satire so liberal? Psychology of Popular Media Culture, 8(2), 134-147. doi: 10.1037/ppm0000157 